\title{
Towards an integrative approach to sustainability: exploring potential synergies between gender and environment
}

\section{Isabel Pla Julián and Sandra Guevara de Molina}

ABSTRACT

KEYWORDS

JEL CLASSIFICATION

B54, Q01, Q57

AUTHORS

Isabel Pla Julián is a senior lecturer at the Department of Applied Economics, Faculty of Economics, at the University of Valencia (Spain). isabel.pla@uv.es

Sandra Guevara de Molina is a PhD candidate at the University of Valencia (Spain). sanguede@alumni.uv.es 


\section{I}

\section{Introduction}

In recent years the world has been facing the most severe crisis since the Great Depression, and the outlook is gloomy. A wide range of economic and financial measures have been implemented, focusing mainly on re-establishing macroeconomic equilibrium, reducing the fiscal deficit, averting the collapse of financial institutions and, more recently, recovering economic growth. Growth is still thought to be the panacea for all the major economic ills of the modern world (Daly, 2005), despite the fact that recent research carried out in some countries finds no significant correlation between growth and human development (UNDP, 2011).

The crisis has exacted a heavy human toll, affecting workers' income, increasing the vulnerability of marginalized people, restricting access to health and education, and exacerbating conflicts. The extent of the impact of these problems is influenced by factors such as gender and geographical region. At the same time, natural catastrophes, desertification and biodiversity losses are also wreaking havoc, particularly among vulnerable groups. It has been 20 years since the United Nations Conference on Environment and Development, which shone a spotlight on the serious ecological deterioration of our planet and its implications for human well-being, and yet we are still facing the same problems, compounded by new challenges that have resulted from the absence of a global perspective and the limited action taken. Some progress has been made, but we are still far from achieving sustainable development. The United Nations Conference on Sustainable Development (Rio+20) emphasized the great importance of growth (but from the perspective of a green economy), as well as the need for institutional arrangements that foster sustainability.

In this context, it is important to acknowledge that sustainable development cannot be achieved without recognizing the services that ecosystems provide for us and the persistent inequalities in our societies, such as those associated with gender, race and sexuality. According to Novo (2007), no one (men and women alike) can make progress without the support of a nature that has not been sacrificed to purely economic interests, and no one, including men, can truly experience dignity in an unequal world in which $70 \%$ of the planet's poor are women. In order to recognize the interconnections between people from different parts of the world, and between human beings and ecosystems, it is necessary to dismantle dualisms such as public/private, feminine/ masculine, reason/emotion, and progress/conservation (Plumwood, 2002). These dualisms entail a hierarchical conception (Bosch, Carrasco and Grau, 2003) that permeates the economic model and defines social behaviours and public policies.

These challenges have yielded substantial debate and a broad research base. Ecofeminists have highlighted the need to challenge the invisibility of women, which shares many characteristics with the invisibility of nature. Feminist economists have made valuable efforts to include recognition of domestic work in theoretical and methodological frameworks. Ecological economists, for their part, stress the need to take into account the principles governing nature in order to achieve sustainable development. The power relations and values underpinning the socioecological system that we - human beings and nature- constitute must be revised. These proposals could be enriched by incorporating a wider variety of perspectives, leading to the adoption of the kind of holistic approach that should characterize sustainable development. In this paper, we explore the possible synergies between ecology and feminism, and the ways in which these two areas could be mutually reinforcing, and express our support for public policies, advocacy activities and positive action to propel the urgent changes that are required. Following our reflection on these issues, we outline an integrative approach to sustainability with a view to fostering a better understanding of the challenges that we face and the need for cross-cutting, systemic policies.

Following this introduction, section II examines the possible transformation of the prevailing Western economic model by incorporating ecological and feminist perspectives, with particular reference to ecofeminism and feminist economics. Section III identifies some existing spaces for moving towards an integrative vision that encourages sustainable development through a change in values, development model and power relations, raising the profile of women's work and outlining a integrative vision of sustainability. Lastly, section IV contains the conclusions of the study. 


\section{II}

\section{Changing the prevailing economic model: incorporating different perspectives and identifying commonalities}

The call for a transformation of the prevailing economic model is not new and has, in fact, been issued by ecological economists and feminist economists alike, as well as other groups whose emphasis is on examining the roots of our problems. The approach adopted by ecofeminists, for instance, focuses on the close interrelationship between human beings and nature, how gender inequalities impact development in the current structure, and the many challenges being faced by women around the world due to their limited access to economic resources and their relationship with nature. Other approaches highlight the need to revise the very conceptualization of economics and development. There follows an examination of each of the two perspectives that make up ecofeminism.

\section{The ecological perspective}

Environmental issues currently feature on both international and domestic agendas. It is important to acknowledge the progress that has been made since the 1960s, when ecologism emerged as a groundbreaking movement. In its earliest form, the movement's main concerns were species preservation, pollution control and protection of natural resources. In Silent Spring, published in 1962, Rachel Carson sounded a warning concerning the terrible impact of agrochemicals on human health (Nash, 1989). Furthermore, the increasing frequency of civic demonstrations, reports on the severity of widespread ecological damage (for example, The Limits to Growth, published by Meadows and others, 1972) and the 1973 and 1979 oil crises all helped to raise public awareness of the impact and extent of environmental damage. As a consequence, new laws to protect species and to prevent and control pollution were enacted at the national level; and significant action was also taken at the international level, examples of which include the Man and the Biosphere Programme (1970) of the United Nations Educational, Scientific and Cultural Organization (UNESCO) and the United Nations Conference on the Human Environment (1972), which led to the creation of the United Nations Environment
Programme and the first steps towards constructing an international legal framework on environmental issues (Vig and Axelrod, 1999).

Those initiatives took a structural approach to the problems, using conventional models of economic and technological development (Humphrey, 2001). From an environmental economics perspective, pollution is a negative externality caused by the absence of a market price for the environment. Solutions to this problem could therefore include imposing taxes to internalize the cost, as proposed by Pigou (1946) or assigning value to natural resources through the development of property rights (as suggested by Coase). ${ }^{1}$ Other economic tools have subsequently been developed to value biodiversity, address climate change and meet different environmental challenges.

As more is known about the impact of anthropogenic activities on ecosystems, more comprehensive approaches have emerged that consider the functioning of the economic system as a whole. These new approaches call into question the prevailing model, which undermines the very material base that serves as its support (Daly, 1996; Naredo, 2006). As a result of this rupture, an unusual form of economic growth has taken place with complete disregard for the planet's carrying capacity. ${ }^{2}$ This has been possible owing to a relatively abundant stock of natural resources and the view that science is capable of generating substitute materials and ensuring a smooth adaptation to the changes brought about in ecosystems as a consequence of their exploitation (Costanza, 2003). Furthermore, economic development has been decoupled from the inequality, exclusion and discrimination it has caused, as these problems are considered to be beyond the scope of economics (Naredo, 2006). Therefore, ecologists would prefer a more

\footnotetext{
1 For more on the differences between these two approaches see Grossman (1999, pp. 538-568).

2 "Carrying capacity" refers to the availability of resources to satisfy a species' needs in order for it to survive, grow and reproduce itself, without having a negative impact on the stability of the system and its resilience.
} 
comprehensive economic model that takes ecosystems and their resilience into consideration, ${ }^{3}$ while proponents of ecological economics, human ecology and political ecology (among others) stand for a broader approach that takes into account the interactions between human beings, nature and distribution.

The Millennium Ecosystems Assessment highlights the link between ecosystems, economic activity and wellbeing, as well as between poverty and the environment. It underlines that ecosystems not only satisfy basic needs in connection with food, medicines, energy, health and safety, for example, but also provide us with services, including the purification of air and water, climatic conditions and spaces for cultural, spiritual, recreational and educational purposes. The assessment drew attention to the fact that our increasing demands have led to unprecedented changes in ecosystems over the last 50 years. These include a considerable — and largely irreversible — loss of the planet's biodiversity and shifts in climatic conditions, which have diminished nature's capacity to offer its key services to humanity. This situation leaves the world population in a vulnerable position, in particular the approximately 2 billion people (DESA, 2009) who live in dry regions and who are prone to suffer disproportionately from deprivation, illness and poverty. This situation exacerbates inequalities and disparities between different groups and generates social conflict (UNEP, 2005). Despite some recent progress, $22 \%$ of the total population of Latin America and the Caribbean lacks access to tap water and $45 \%$ of the rural population lacks sanitation services - two factors which have a direct impact on health and mortality rates. An estimated 35 million to 40 million people do not have access to basic energy services (electricity and fuel), and around 35,000 people die annually from causes relating to air pollution, while climate change, poverty and biodiversity loss are heightening vulnerability to natural disasters, which has already had a serious impact on the region's economy and population (ECLAC, 2012).

Meanwhile, these problems do not affect only those suffering as a direct consequence of deprivation or natural catastrophes. In their struggle to overcome such situations, the options available to those affected might represent a threat to others and thus lead to social conflict, insecurity, wars or migration flows to more resource-rich, peaceful or stable countries. Similarly,

\footnotetext{
3 "Resilience" in ecology refers to the capacity of ecosystems to absorb disturbances and reorganize while undergoing change so as to retain - essentially - the same function, structure, identity, and feedbacks (Walker and others, 2004).
}

an economic activity in a particular area might affect not only the immediate environment, but also that of a neighbouring region or country, thus giving rise to international tensions. In short, human beings and nature are not independent from each other; on the contrary, they compose a socioecological system which has to be managed as a whole (Young and others, 2006; Bono, 2008a). Greater understanding of this fact has generated more integrative approaches, such as political ecology, social ecology, human ecology and deep ecology.

Since a world in which poverty and inequality prevail will always be inclined to social, ecological and other crises, the authors of the Report of the World Commission on Environment and Development: Our Common Future (also known as the Brundtland Report, 1987) suggested pursuing a form of development "that meets the needs of the present without compromising the ability of future generations to meet their own needs" (United Nations General Assembly, 1987). This does not mean that all generations must leave the world as they found it: what must be preserved are the opportunities so that the future generations can have substantial freedoms, take decisions and enjoy life (Bono, 2008a). The concept of sustainable development seeks to integrate ecology, the economy and society, and was at the heart of the United Nations Conference on Environment and Development (also known as the Rio Summit) held in 1992.

Nevertheless, some authors consider "sustainable development" to be an oxymoron (Naredo, 2006; Redclift, 2009) since it does not question economic growth in itself, only its sustainability from a social and environmental point of view. However, it is vital to bear in mind that in order for any concept of development to receive backing at a multilateral meeting it must satisfy the needs of countries with disparate realities. An impoverished country cannot be denied the right to grow its economy or pursue a better standard of living, even though the way in which it does so is important and growth per se does not necessarily lead to better standards of living for the population. It is therefore crucial to take into account the social, environmental, technological and cultural factors, among others. The situation in developed countries is different: in their case, production and consumption patterns are the key issue and questions can be raised regarding the pursuit of unbounded growth.

This debate is particularly relevant nowadays, since the terms "sustainable development" or "sustainability" are included on most national and international agendas. Since the adoption of Agenda 21 at the Rio Summit in 1992, most countries and many cities have been working 
on their corresponding sustainable development action plans, with an emphasis on addressing environmental, economic and social issues simultaneously. However, in many instances the term "sustainable development" is used for marketing or publicity purposes, with or without a solid basis. The ecological movement offers several alternative views on the limitations of nature as a system, which can be perceived as determinist, adaptive or innovative depending on whether the natural environment is considered to be cardinal, replaceable or not always replaceable (Costanza, 1994). In the quest for environmentally sustainable human development, technology will play a key role in decoupling growth from pollution and environmental degradation (Almenar, 2008). Certainly technology and knowledge influence the nature of output (Schmid, 1987); however, institutions have the potential to spur ecologically informed technological advances by providing a framework for the transformations that development requires (North, 1990).

All these aspects are brought together in another, more comprehensive notion of sustainable development that goes beyond the interactions between the environment, the economy and society and posits sustainable development as a global transformation of society, not only in terms of goals, but also of means. Thus, in addition to satisfying human needs while respecting the planet's carrying capacity, this new vision incorporates technology and institutions as two additional fundamental pillars (Tomás Carpi, 2007 and 2008). The core values underpinning this notion include eco-efficiency, solidarity and social activism, which make it a good starting point for exploring synergies with feminist ideology in the quest for an integral conception of sustainability.

The outcome document of the Rio+20 Summit ("The future we want"), in addition to promoting a green economy in the context of sustainable development, calls for a political commitment to reinvigorate the global partnership for sustainable development, as well as to improve capacity and coherence at all levels, integrating sustainability into all levels of both public and private decision-making (United Nations Conference on Sustainable Development, 2012).

\section{The feminist perspective}

Feminism, like ecologism, takes many forms, each one influenced by the particular experiences of women from different parts of the world. Initially, feminist demands related mainly to the right to education (Rivera, 1991) and, later, to the right to vote (Freedman, 2004; Rivera, 1991). The Second Sex, published by Simone de
Beauvoir in 1949, is considered the cornerstone of new feminist vindications (Freedman, 2004; Sánchez, 2001). According to Valcárcel (2008), it prompted numerous theoretical explanations of the subordination of women. It also influenced advocacy movements throughout the world, which led to a progressive increase in women's participation at the institutional and public levels and the introduction of active policies to foster their involvement from then on.

Diverse viewpoints can be found in black feminist theory — referring to African-American stances - and among the views of feminists from developing countries (Freedman, 2004; Mies and Shiva, 1997). Their ideas on multiple identities and the interplay of a range of factors that determine inequalities (such as race, ethnicity, cast, culture, religion, economic level and sex) enriched the feminist perspective, while also introducing some discrepancies. Nonetheless, despite their differences, all of these ideologies share the common goal of ending the oppression of women (Howie and Tauchert, 2002).

It was precisely in the context of black feminism that the concept of "ecofeminism" took shape. The term is attributed to the French writer Françoise d'Eaubonne (Mellor, 1997) and combines a gendered view of humanity (represented by the colour violet) with ecologism (represented by the colour green). The concept represents a challenge, and —at the same time- a significant contribution to both feminism and ecologism (Plumwood, 1993; Moore, 2004). Given the plurality of these two movements, their convergence has generated a wide range of ecofeminist theories. These encompass activism and valuable political and theoretical contributions to sustainable development. The emphasis of ecofeminism varies according to the perception of the link between women and nature (depending on the particular branch of feminism or the depth of the treatment of environmental issues), as well as the specific area of concern or context in which those reflections originated, especially the historical and material conditions of women's lives (Mellor, 1997; Kao, 2010). Such diversity is easily appreciated by reviewing some of the arguments put forward by ecofeminists. In Feminism or Death (1974), D'Eaubonne blamed environmental degradation on the patriarchal system, which exploits nature as it submits women (Agra Romero, 1998). An opinion shared by King, for whom the devastation of the Earth can be attributed to the same masculine mentality that seeks to deny women of the right to control their own bodies and sexuality through various control mechanisms at the personal and State levels (Merchant, 1995; Agra Romero, 1998). 
The Chipko movement ${ }^{4}$ began as a group of women who sought to stop deforestation in the northern part of India in order to preserve their community's source of well-being in a subsistence economy (Mellor, 1997; Merchant 1995; Mies and Shiva, 1997). Similarly, the Green Belt Movement ${ }^{5}$ in Kenya, founded by the Nobel Peace Prize laureate Wangari Maathai in 1977, began by addressing growing deforestation, soil erosion and water scarcity by planting trees (Merchant, 1995). It later evolved into a movement advocating human rights and the sustainable management of resources, as well as supporting good governance, democratic principles and peace. One of the ecofeminist pioneers in Latin America was the Italian-Venezuelan biologist and architect Giovanna Merola, whose vision was to integrate human beings into their natural and urban environment using a feminist approach (Salleh, 1997).

Different classifications of ecofeminism have been proposed (see Agra Romero, 1998; Merchant, 1995; Mellor, 1997; or Puleo 2002 and 2007, among others) and although labelling can be difficult and sometimes limiting or controversial, we believe that reviewing some of those categories here could be helpful. Essentialists or classic ecofeminists argue that women are better prepared than men to solve ecological crises since they are inherently caring and protective, while men are, by contrast, in essence competitive and destructive (Puleo, 2002). Affinity ecofeminists take the more inclusive view that the link between women and nature derives from culture and traditions, rather than being rooted in biology (Mellor, 1997). The constructivist approach is similar as it considers this link to be a sociohistorical construct used to exercise patriarchal control. This view emphasizes the political over the personal (for more on this approach see Biehl, 1991; or Heller, 1999).

There is a tendency to associate ecofeminism with its spiritual strand, that is, the one which assumes that women and nature share a metaphysical or ontological bond, though opinion varies significantly as to what this entails and the desired level of political involvement. A major exponent of ecofeminism, Vandana Shiva (1993 laureate of the Right Livelihood Award, often referred to as the "Alternative Nobel Prize") points out that Western technical development is a source of violence

\footnotetext{
4 A green movement made up mainly of impoverished small-scale farmers and craft workers in India. ${ }^{W_{\text {Omen }}}$ account for a large proportion of this social movement whose philosophy is based on the Gandhian concept of non-violent resistance.

5 An environmental organization in Africa which promotes biodiversity conservation and empowers communities, particularly women.
}

against women and nature, and calls for an ecologically sustainable model based on the ontological conception of the feminine as a trans-generic principle and on the unbreakable continuum of society and nature. Women and nature are, undeniably, creators of life and productivity beyond the bounds of the processes of capital accumulation (Mies and Shiva, 1997). Ivone Gebara, one of the main proponents of theological ecofeminist thought in Latin America, equates social justice with ecological justice (Puleo, 2002 and 2007; Kao, 2010). Other spiritual approaches, both in the region and in other parts of the world, are influenced by indigenous cosmogonies and by women's daily experiences (Ress, 2003).

Indian economist Bina Agarwal proposes a feminist environmentalism that considers the women/nature bond as rooted in the family economy, where gender responsibilities are assigned. She holds that excellent examples of environmental protection measures that could be scaled up can be seen at the family level. In her view, the connection between development, redistribution and ecology requires a transformative perspective, since the aspiration to technological control undervalues women, nature and feelings (Agarwal, 1992). Alicia Puleo (2008) proposes an enlightened ecofeminism, conceived of as an ethical and political project that calls for equality and women's autonomy - regardless of their social, cultural or ethnic provenance. That approach accepts, with caution, the benefits of science and technology and promotes the globalization of values such as the ethics of care towards human beings and nature, recognizing the unity and continuity between them (from an evolutionist point of view), as well as compassion.

Meanwhile, the distribution of and access to natural resources is a key component of feminist political ecology. The critical variable, according to this approach, is how social class, cast, race and culture interact with gender. For its exponents, there are three key elements: (i) gendered knowledge, that is, the wisdom of survival developed by women in order to maintain and protect a healthy environment at home, as well as in their workplaces and communities; (ii) gendered environmental rights and responsibilities, meaning differential access to property, resources, public space, legal rights and common law, and (iii) gendered organizations, which refers to the political-environmental activism in which women are increasingly involved, thus redefining their identity, the meaning of gender and the kind of environmental problems faced (Rocheleau, Thomas-Slayter and Wangari, 1996).

One point that all of these strands of ecofeminism have in common is the "invisibility" of women and nature owing to their devaluation by male-dominated 
systems of scientific knowledge and economic power (Stoddart and Tindall, 2011). According to Novo (2007) the reason is that women do not produce a surplus value. She emphasizes the need to reassess the "civilization footprint", that is the energy dedicated in terms of time, affection, love or care that people require to satisfy their real needs, as well as the "ecological footprint" left on the planet by the demands of our lifestyle. Both Shiva and Novo state that when life cycles function well and remain effective, they become invisible to our eyes. As a consequence no value is attached to them unless these cycles are disrupted. Plumwood (1993) uses the term "backgrounding" to describe one of the ways in which both women and nature have been devalued.

For feminist economists, considering only paid work to be "productive" makes reproductive and domestic work — performed mainly by women — invisible in economic terms (Durán, 2001 and 2012). Hence, socioeconomic policies and programmes that have been designed from this perspective are ineffective in redressing gender inequities (Carrasco and Mayordomo, 2000). Furthermore, failing to assign an economic value to such work leads to a general underestimation of women's contribution to development, particularly in relation to intangible elements such as emotional support, encouragement, skills stimulation, family relations and nurturing (Bosch, Carrasco and Grau, 2003). This inequity is not limited to the privacy of homes or the work environment, rather it permeates all areas of life: from academia to enterprises, as well as the social and political representative institutions of almost all societies.

Australian philosopher Val Plumwood (2002) has stressed the need to transcend the hierarchical dualisms of nature/culture, women/men body/mind, matter/spirit and affection/rationality. These constitute the basis for the debasement of nature and reflect an arrogant Western philosophy that has at its core a dominant male self, separated from his own body and feelings, from women and the rest of humanity, as well as from the Earth that supports him. This has led to calls for a conceptual framework which takes into account the interrelation between the subjugation of women and nature, and for a re-conceptualization of feminism and environmental ethics that opposes the logic of domination and, at the same time, recognizes values such as care, love and friendship (Warren, 2009). Salleh (1997) calls for a new fair and human contract with nature, arguing that men's oppression of other men, women and nature may only be dismantled by transforming the economic model.

Notwithstanding the achievements of feminism over the last two centuries, significant and unsustainable inequities remain. This explains the aspiration for substantial changes and the need for development policies. In our opinion, a larger development impact could be made by consolidating a more coherent and comprehensive approach that combines gender and sustainability.

\section{III}

\section{Spaces for synergy: towards an integrative vision of sustainable development}

The complexity of the problems addressed by feminists, ecofeminists and ecologists of all shades is undeniable and despite commonalities there are also disagreements. ${ }^{6}$ For example, while anthropocentrism is one of the main concerns of ecologists, feminists accuse environmentalists of failing to question the patriarchal system and of

\footnotetext{
6 Many articles have been published regarding this debate: Zimmerman (1987); Warren and Cheney (1991); Plumwood (1993); Sessions (1991); and Bosch, Carrasco and Grau (2003) are some of the authors who have discussed in depth the points on which feminism and ecologism coincide and where they differ.
}

leaning on prevailing mechanisms and control structures (Bosch, Carrasco and Grau, 2003). Instead of adding to the debate, in this article we prefer to explore the areas in which these different movements coincide and try to close the gap between the two schools of thought. First, because positions are not homogeneous on either side and, in any case, have a tendency to evolve. Second, because gender inequities, social tensions, economic and financial costs, and the poverty afflicting billions of people around the world, as well as the accelerated pace of biodiversity loss, climate change, desertification, among other severe environmental problems which affect human 
well-being, call for an integrative and multidisciplinary approach that incorporates the diverse aspects of reality (Bono, 2008b; Young and others, 2006).

\section{The invisibility of women and nature}

As mentioned above, domestic and reproductive work has long been underestimated by society in general and by economists in particular, which has resulted in its becoming invisible, despite the fact that homes are akin to service workshops and no other productive sector equals them in terms of the volume or economic relevance of their output (Durán, 2012). Similarly, no value is ascribed to the services and resources provided by nature, whose essential contribution to human wellbeing is ignored, as are the consequences of disruption to natural cycles, which ultimately leads to the irrational use of resources, the degradation of ecosystems and the interruption of biogeochemical cycles. The absence of a market price appears to denote unimportance and entails invisibility (Novo, 2007). It has therefore been argued that assigning economic value to natural resources and to the negative externalities affecting nature would promote sound environmental management (Kriström, 1995, cited in Salvador del Saz, 2008).

Valuation systems, sustainability indicators, tax reform proposals, environmental management systems and environmental impact assessments, legal frameworks to penalize or prevent further environmental pollution and degradation are all commendable suggestions to help address the invisibility of nature. However, these two areas could be incommensurable (Martínez-Alier, 2007), in which case a more holistic approach that reflects the way in which ecosystems work might be more appropriate.

In the same vein, making visible the total amount of work done by women is a complex task, since it involves a multidimensional conception (in terms of time and space) framed by formal and informal institutions that are difficult to change: all of which represents a farreaching challenge. Carers carry out many physical tasks, including curing and cleaning, and they must be vigilant (to avoid incidents and prevent illness), but they are also responsible for family management, representation and communication. These elements are difficult to separate conceptually and even more difficult to quantify in terms of time and value (Durán, 2011).

There are several proposals, linked to the mandate emanating from the Beijing Declaration and Platform for Action, aimed at modifying the conceptual framework or improving the statistical tools to make unpaid work visible. Picchio (2005) suggests reformulating the cycle of market production and distribution; while Durán (2001) proposes improving national accounts by using household satellite accounts that attribute a monetary value to domestic and care work. The Statistical Office of the European Communities (EUROSTAT) and the Economic Commission for Latin America and the Caribbean (ECLAC) have carried out time-use surveys, which for the time being are considered the best available tool (Durán, 2012). Carrasco and Mayordomo (2000) developed a non-androcentric survey of the active population; while Carrasco and Serrano (2011) created a new methodology that captures information on both household and market activities, overcoming some of the limitations of the databases currently used to calculate household satellite accounts. In Latin America, great progress has been made in this area through the use of various methodologies, particularly special modules in regular home surveys (Durán and Milosavljevic, 2012). All these tools have contributed a great deal to demonstrating the extent of prevailing gender inequalities and the subordination of women, which represents a public policy challenge (Rodríguez Enríquez, 2012).

Picchio proposes a reformulation of the cycle of market production and distribution, reframing not only the conditions of market production, but also the conditions for the reproduction of the labour force. She highlights that domestic activities and care work carried out within the family sphere enable family members who engage in paid work outside the home to continue to do so. She distinguishes between three key economic functions for human development at the household level: first, the extension of monetary income or real wages through the provision of goods, meals, clean clothes, etc.; second, the expansion of well-being by fostering human capabilities and effective functioning in the social sphere; and third, the support lent by the family unit to the selective processes that take place in the market economy in terms of the skills used in the process of producing goods and services. Picchio (2001 and 2005) defines an economic space devoted to human development and composed of activities whose direct purpose is the well-being of individuals and not the valuation of goods (see figure 1).

The model addresses key aspects of invisibility and highlights the constant interaction between paid and unpaid work, the difficulty of assigning a monetary value to domestic work (Durán, 2012) and its ability to transform living standards into well-being (Rodríguez Enríquez, 2012). Nevertheless, the economy-nature disconnect of the prevailing economic model is replicated, 


\section{Extended standard of living cycle}

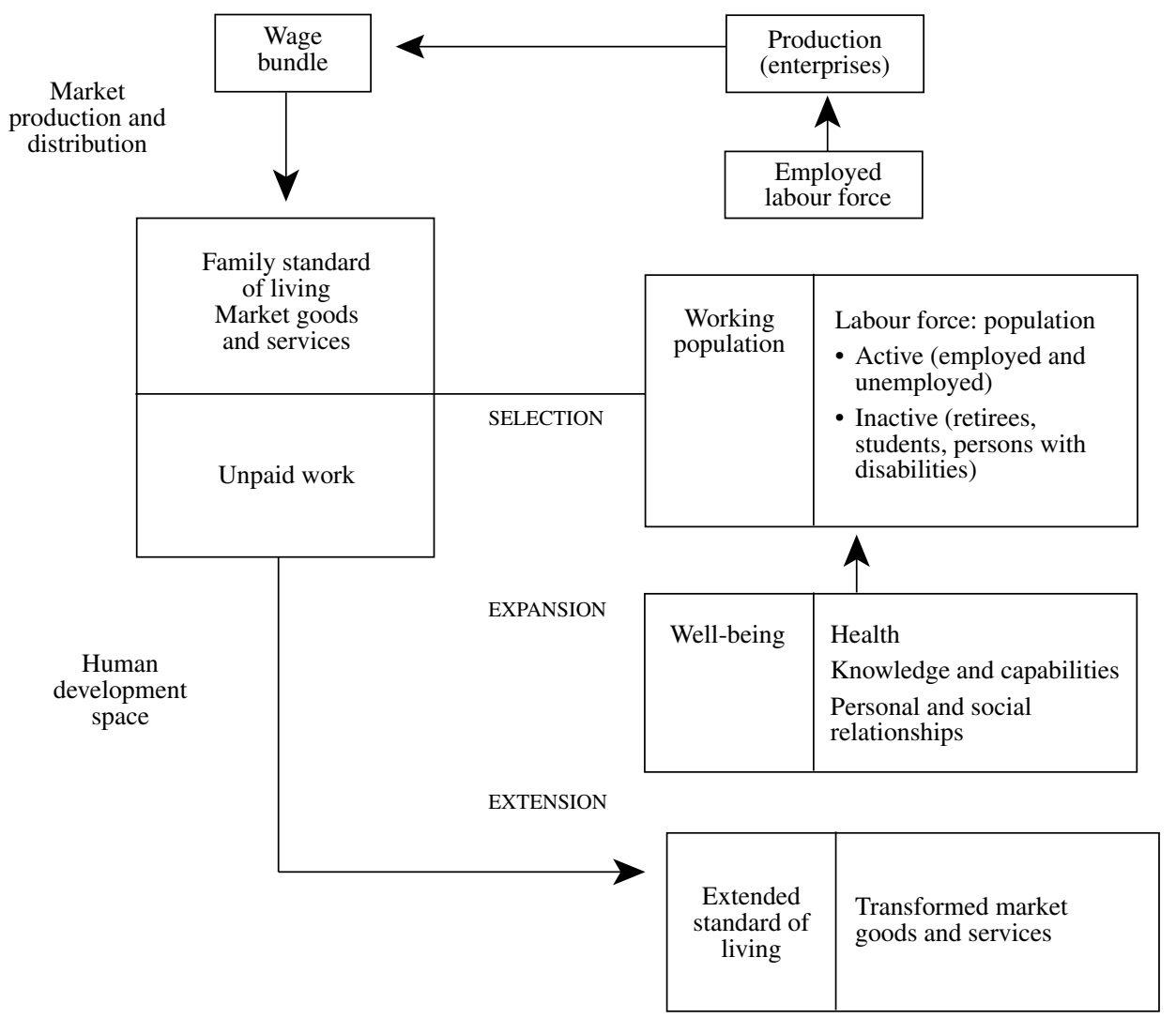

Source: Antonella Picchio, "La economía política y la investigación sobre las condiciones de vida", Por una economía sobre la vida, Gemma Cairó i Céspedes and Maribel Mayordomo (comps.), Barcelona, Icaria-Más Madera, 2005.

indirectly reinforcing the invisibility of nature. In order to integrate the ecological perspective, the entire cycle would have to be reframed with respect to nature, and this would require an acknowledgement that market production and distribution, as well as all the activities relating to human development, depend on the resources and services provided by ecosystems (biogeochemical cycles, spaces, information) and that such activities generate pollution and waste and lead to the degradation of biodiversity, which sooner or later will have an impact on human well-being. These exchanges with nature (inputs and outputs) should be taken into consideration, in addition to the resilience capacity of nature, in order to ensure sustainability. In this way, both invisibilities would be addressed at the same time.

Introducing a temporal dimension into this model would further widen its scope. Nature needs time to recover from certain impacts, which is similar to human resilience capacity. Future generations' right to satisfy their needs is linked not only to the use of goods and services provided by nature, but also to the performance of reproductive activities and the provision of care and support, which have traditionally been carried out by women. Durán (2011) refers to an implicit intergenerational social contract, that is, a deferred exchange in which the care and services received are returned to the providers over the medium or long term, or are passed on to the next generation. In addition, it is necessary to emphasize the need for women and men to share domestic responsibilities. In recent history, that absence of shared responsibility in the home has led to a significant shift as those tasks are transferred between women in different parts of the world. Indeed, global demand for domestic workers constitutes one of the reasons for the feminization of migration, giving way to a global care chain (Durán, 2012; Hochschild, 
2004; Pla, 2009). Along the same lines, solidarity with marginalized people is a key consideration for sustainability, and ways to include this element in the model should be explored further.

\section{A change in values}

In order to truly address gender disparities and environmental challenges, the way in which value is ascribed to women and nature must change since that value determines social behaviour towards them. Making visible the tangible and intangible activities that are performed at home and that facilitate the smooth functioning of the whole economic system is certainly important; however, it is also necessary to stop considering these activities as a gender duty, and especially as one which can be replaced by commoditized work in precarious conditions (Pla, 2008). The distribution of domestic work is part of the sexual division of labour determined by cultural patterns and economic rationality (Rodríguez Enríquez, 2012). Dismantling the patriarchal culture that underpins gender inequalities requires new symbolic content in the collective memory (Montaño, 2010). Similarly, reassessing the significance of ecosystems for human well-being and the impact that anthropogenic activities have on them (Costanza, 2003; Nash, 1989) calls for more than conducting environmental impact assessments, assigning economic values to resources or trying to use them more efficiently: rather we must redefine our current lifestyle, which is characterized by excessive consumerism and represents an oversized burden on the planet. That burden compromises ecosystems' capacity for self-regulation and the availability of resources and services, now and in the future. Several proposals have been put forward to address this challenge and longstanding discussions on consumption and production patterns have been taking place under the aegis of the United Nations Commission on Sustainable Development, although no significant progress has yet been made.

To make a change in social behaviour, more emphasis should be placed on education for sustainability in order to raise public awareness and foster the adoption of these new values. Understanding that we do not need to have more but to be better is essential. The United Nations Educational, Scientific and Cultural Organization (UNESCO) has been actively involved in promoting action for the United Nations Decade of Education for Sustainable Development, 2005-2014 (United Nations General Assembly resolution 57/254, 2003). As stated in the Bonn Declaration of 2009, education for sustainable development "should actively promote gender equality, as well as create conditions and strategies that enable women to share knowledge and experience of bringing about social change and human well-being" (UNESCO, 2009). This has led to important initiatives worldwide on mainstreaming gender equality in all areas under the UNESCO implementation scheme, including the preparation of guidelines and tools for gender sensitizing as part of the guidance provided to teachers within the framework of the Decade of Education for Sustainable Development. Another important step forward is the Earth Charter Initiative, through which civil society organizations all over the world have been promoting the transition to a more sustainable lifestyle (Bosselmann, 2004).

These initiatives should be accompanied by appropriate institutional support at the national and local levels, which would indicate a shift in the priority given to environmental and gender issues in public policies. Those issues should be reflected in all socioeconomic regulations and policies, as well as in formal education programmes (at the primary, secondary and tertiary education levels), which should integrate these subjects into existing programmes of study, particularly economics and business courses, instead of introducing them as separate subjects disconnected from the rest of the curriculum. In terms of informal education and raising public awareness, establishing alliances with the media is critical. Broadcasters should be encouraged to embed topics relating to ecological and gender ethics in their prime time programming, replacing the patriarchal, materialistic and short-sighted vision currently being promoted in the majority of the programmes that are broadcast. The use of gender counter-stereotypes, that is, presenting certain positive values as feminine stereotypes until they are accepted beyond question, (Jolly, 2004) has been powerful tool for effecting change. UNESCO has developed a set of Gender-Sensitive Indicators for Media, which address the intersection of women's empowerment and media development, and has provided training to journalists in order to enhance their reporting activity on issues related directly or indirectly to women.

Another aspect that deserves to be revalued is the contribution of rural women to nature conservation, as mentioned above. This contribution is not motivated by essentialist views or a desire to return to pre-capitalist practices, but by the cumulative experience of these women whose close relationship with the environment is valuable for preserving ecosystems. They have learned not to sacrifice nature for immediate profits and to give priority instead to the steady supply of food, shelter, energy, water, medicines and other goods and services that nature provides for their families. A greater appreciation 
of this approach would help to strengthen tolerance and understanding of cultural differences - a major concern of ecofeminist movements in Latin America.

It is necessary to recognize the continuous interrelation between ecosystems and people all over the globe. This interconnection in the socioecological system (Young and others, 2006; Bono, 2008a) is such that impacting just part of it affects the global balance and that is why it is important to conduct global environmental assessments and ensure fairer distribution practices and international justice. The severe poverty afflicting a third of the world population, ${ }^{7}$ the feminization of poverty 8 and the transfer of inequities between women of different nationalities, social statuses, races and education levels through the global care chain (Hochschild, 2004) are all factors that point to the need to address this problem. According to Valcárcel (1993), equality should be enjoyed by humanity as a whole, but to date it is not. Instead, our societies marginalize lower-income sectors, and the rest of the world remains oblivious to the problem. She holds that nothing can be done to change the prevailing order without equality. Along similar lines, Tomás Carpi (2007) stated that sustainable development had to be pursued globally or it would not exist at all. The Human Development Report has recently pointed out that a combined approach must be taken to tackle the urgent global challenges of sustainability and equity (UNDP, 2011). The aim here is not to present a catastrophic discourse, but rather to channel our creativity in order to merge the ecosystems approach with the gender approach in order to promote appropriate policies and actions.

\section{Restructuring power relations}

The Gender Inequality Index included in the Human Development Report (UNDP, 2011) ${ }^{9}$ and the Gender Equity

\footnotetext{
7 The Multidimensional Poverty Index, which includes data on 79\% of the world population, estimates that $31 \%$ of the world population (1.65 billion people) can be identified as multidimensionally poor (UNDP, 2011).

8 In Latin America, the feminization of poverty index produced by the Gender Equality Observatory of ECLAC clearly shows that in almost all countries and areas (rural and urban) poor women outnumber poor men, a gap which is particularly significant in women aged 20-59 years in the majority of countries.

9 We are aware of the criticisms levelled at the methodology used by the United Nations Development Programme (UNDP) to calculate the previous Gender-related Development Index and Gender Empowerment Measure; however, these criticisms do not deny the existence of inequalities, but rather the way in which they should be calculated. The suggested adjustments could lead to worse scores for some countries (see Klasen and Schüler, 2011).
}

Index developed by Social Watch (2012) clearly show that, although there are significant variations between countries, in general, women work more, earn less, make up a larger proportion of the illiterate population among those living in absolute poverty, have less access to education, are less likely to hold managerial positions or participate in representative institutions, have poorer diets, receive worse health services and are more likely to experience gender-based violence or be deprived of the right to be born, among other unfair practices (Social Watch, 2011). According to statistics on the employed population aged 15 years and over produced by the Gender Equality Observatory of ECLAC, Latin American women work between 8 hours and 23 hours more per week than men (paid and unpaid work), and that gap ranges between 22 hours and 28 hours per week for the unemployed population. In addition, an average of $34.7 \%$ of women have no income of their own, which reflects their lack of autonomy and lower participation in the labour market. ${ }^{10}$ Despite being the main care providers in the home, they are labelled "inactive" for the purposes of traditional labour statistics (Montaño, 2011).

The unequal distribution of power and the various obstacles to women's active participation in decisionmaking processes at the household, community and society levels also limit women's ability to exercise their rights and citizenship, and are directly related to women's lack of social protection and security (ECLAC, 2004). As mentioned above, feminists argue that gender disparities are linked to hierarchical power relations, a point of view that they share with some ecologists, who draw attention to the dominance exerted by the strong over the weak, whether that refers to people or countries. A redefinition of power relations is as necessary to relations in the private and public domains, as it is to personal and international relations. In this sense, acknowledging and then valuing the other (women or nature) should lead to equal treatment, equal rights, and equal opportunities to develop capabilities, with respect for the relevant cycles and time frames. Ethical and political reasons have not been persuasive enough to bring about a change so far, neither within our societies nor in the world order. Instead, economic interests and resistance to power-sharing have prevailed. Efforts are urgently needed to foster inter-gender and intra-gender justice and equality of rights and opportunities, with a view to bringing democracy and equity to personal and

10 Statistics from the Gender Equality Observatory of ECLAC. 
international relations. This will put pressure on access to the resources and technologies required to advance towards women's empowerment and to an inclusive conception of sustainable development, but if that does not materialize the negative impact on families, social cohesion, developmental policies, stability and security will intensify, increasing the risks of social, environmental, and economic crisis.

As stated above, environmental problems pose important challenges to global governance owing to the direct and indirect impacts of human activities and the interdependence of ecosystems. Biodiversity loss, for instance, affects the provision of raw materials worldwide; and climate change disrupts ecosystem cycles, also at the global scale. It is therefore crucial to act simultaneously at the local and global levels (Bono, 2008b). Hans Bressers and Walter Rosenbaum (2003) stressed that, because of ecological interdependence, environmental protection must be executed across multiple scales and should be covered by the legal and institutional frameworks in order to address the problems properly. The challenge lies in how to integrate the different geographical scales, as well as the time frames, institutions and sectors involved at each level. That requires collaboration, dialogue and coordinated action among local actors and among countries, based on a non-dominating, integrative and cooperative approach. To that end, a new kind of committed leadership, with a comprehensive understanding of the multidimensionality of the problems, is needed to foster local and global consensus on the required public policies (Tomás Carpi, 2008).

\section{Changes in the development model}

The questioning of the prevailing economic model is common to both the ecological and the feminist perspectives. The ecological movement and research groups have put forward a number of interesting proposals for change based on a systemic and holistic approach that can accommodate feminist concerns. One example is the contribution by Tomás Carpi (2007), cited above. On the means side of his sustainable development model, he points to technological innovation, the environmental management of production processes, institutional change, regulation mechanisms for the economic system, and the evolution of sociocultural and power relations. Regarding the aim of the model, sustainable development aspires to improve the quality of life of human beings and promote social development, democracy and distributional justice, while preserving natural ecosystems' capacity for selfregulation to provide us with products and services.
This proposal comprises several important characteristics, some of which coincide with ecofeminist arguments, while others are more in tune with the feminist economist perspective. First, it is striking that the aim of the model is not to pursue endless accumulation, for it places nature (the environmental pillar) at the same level as the social pillar. Furthermore, it takes into consideration the carrying capacity of the planet to satisfy human needs. Likewise, it considers health as one of the most important relations between human beings and the natural environment - thus paying due attention to a major cause of concern for ecofeminists and ecologists alike. His model includes eco-efficiency, eco-effectiveness and sustainability in the economic pillar, which reveals not only the perception of nature as a fundamental base with strategic functions on which we all depend, but also a long-term perspective, which is essential for intergenerational solidarity. Instead of seeking absolute control over nature, it puts knowledge in the service of ecological limits with a view to developing their joint potential and decoupling development from pollution and environmental degradation. The social pillar incorporates aspects such as quality of life (taking into account the diversity of approaches according to the context), social cohesion, level of awareness, learning processes and capacity-building. The model recognizes that a fundamental transformation is required at the social level in order to achieve the change in values required. Finally, the institutional framework (formal and informal) can promote the adoption of those new values by allocating the appropriate resources and fostering technological progress, resource management, education and the development of instrumental freedoms, among many other things (Tomás Carpi, 2008).

This model clearly represents an advanced notion of sustainability, which is compatible with the gender perspective, and demonstrates an important openness to new values. It stresses equality, solidarity and cooperation, and even changing power relations. Nevertheless, the model could be further enriched by integrating the ethics of care (the European Union has recognized the right to care) and by reflecting the contribution and value of domestic and reproductive work, as proposed by Picchio. Therefore the dynamic relationship between the social pillar and the economic pillar should reflect the fact that household chores contribute to economic activity (tangible and intangible), and the economic pillar should include gender equity as one of its guiding principles.

On the basis of the reflections above, we have developed an integrative vision of sustainability in the socioecological system, which is represented in figure 2 . 


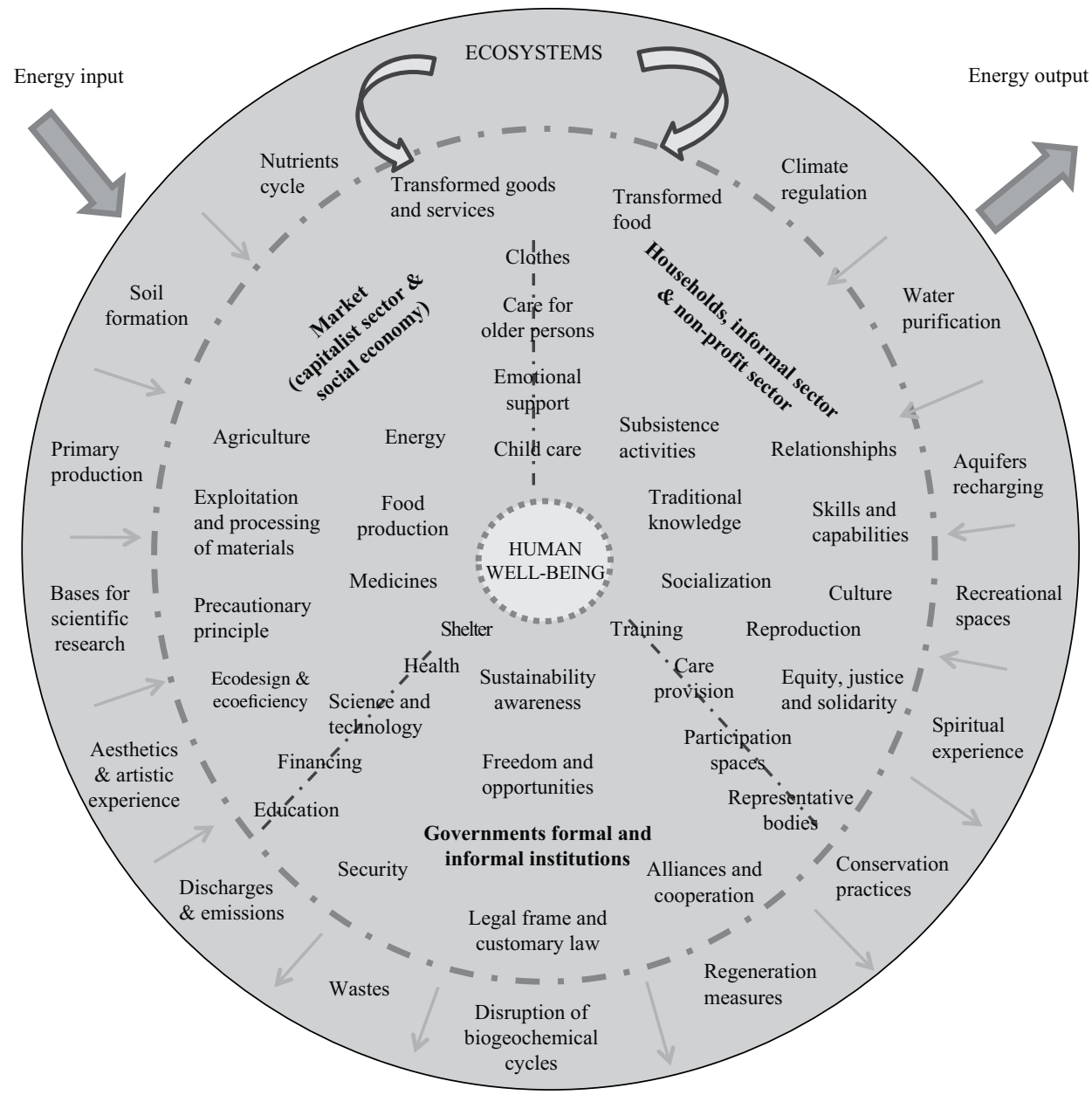

Source: prepared by the authors.

Figure 2 shows a circular and open system. The multiple interactions inside and outside each segment are unlimited and could occur in any number of diverse combinations and in any order. This model recognizes nature as the foundation of all human activities, providing vital goods and services in order to satisfy human needs and absorbing our impact in return. This vision plays down the importance of the market, devoting attention to the non-monetized sphere of the economy too. Care work, essential to the productive and reproductive cycles, is represented not as task to be performed, but as a need to be satisfied (Bosch, Carrasco and Grau, 2003; Carrasco, 2009).

This vision relates to a concept of human wellbeing that is nurtured by both the material and the non-material, which includes: food, shelter, health, financial resources, but also emotional support, freedom of choice, active participation, capacity-building, spiritual experiences, and the right to provide and receive care. All of this requires the components of the socioecological system to function harmoniously, without sacrificing any of the suppliers of these elements. The social and environmental responsibilities of the economic agents guide their activities, as do the precautionary principle and eco-efficiency, always taking into account the carrying capacity of nature. Formal and informal institutions adopt this notion of a multidimensional continuum that forms nature and human beings in space and time. In a contextualized way, it promotes the very actions required to maintain its dynamic equilibrium. To that 
end, technology and traditional knowledge provide us with a better understanding of nature, harmonizing its rhythms with ours and providing us with the means to adapt to changes.

The challenges faced are cross-disciplinary and require a non-dominating, cooperative and integrative approach, as well as a society that is conscious of its individual and collective impact, resulting from what it produces, how it does so, what it consumes and the effects of that consumption. Citizens must be aware of their rights and responsibilities. The active participation and commitment of society as a whole are essential to propel and facilitate such a change. A population that is educated with regard to local and global sustainability, which fosters justice and equity, intergenerationally and

\section{IV}

\section{Conclusion}

As stated in the Report of the World Commission on Environment and Development: Our Common Future, a world in which poverty and inequality prevail will always be inclined to social, ecological and other crises. Economics cannot continue to ignore nature and the world population must have a say in the necessary revision of the economic model. Durán (2011) states that in an effort to focus objectively on goods and markets, economics has forgotten the human beings who produce and consume, as well as those who do not have access to goods and services. The prevailing production and consumption patterns compromise ecological stability, as well as world equity and justice, since they pose a risk to humankind, present well-being and that of future generations. At the same time, persistent gender inequities and the feminization of poverty call for a reassessment, in ethical and economic terms, of women's contribution to society and their right to the same opportunities, with a view to making universal equality a reality. In order to achieve sustainable development everyone must be able to enjoy the same spaces, decide how to use their own time, access resources and represent themselves in political and social bodies. The concept required here - and that as yet remains under construction - is that of an active State as a guarantor of rights (Montaño, 2010). But none of this will be possible if we irreversibly disrupt the characteristics that make life on Earth possible. intragenerationally, is a fundamental part of this conceptual framework. The active involvement of communities and the media in promoting and defending the new values is key to overcoming inter-gender and intra-gender inequities. This can be achieved through effective and active participation in the public arena, in the form of dialogue, alliances and opportunities to present their ideas and proposals. Another priority is creating a new leadership - one that is truly democratic, in tune with needs of today's society and possess a comprehensive understanding of the way that socioecological systems work and their resilience capacity. That type of leadership is vital to ensuring that policies are designed and executed from a holistic perspective and do not need to be adjusted ex post to include limited measures on sustainability.

Proponents of ecologism and feminism are called on to look beyond their disagreements and explore synergies that could help to bring about the necessary transformation of the prevailing model. There is no single, simple or definite formula for achieving this, but there is scope for debate, further research and political action with a view to spurring the changes our society urgently requires.

We should therefore opt for a systemic solution and an integrative vision of sustainability. Picchio's proposed reformulation of the economic cycle to include unpaid domestic and reproductive work would be strengthened by adding an ecological perspective. Her model could be placed within the framework of nature, reflecting the exchanges between humans and nature, and expanding the temporal dimension, thus addressing the concerns of feminists and ecologists alike. But theoretical reforms are not enough to produce the transformations required; both movements agree those reforms must be accompanied by appropriate public policy and changes in fundamental values. There is evidence of advances in legal equality in some contexts, but much remains to be done to expand the scope of those advances and to transform them into effective and consistent behavioural changes on a worldwide scale. A robust alliance is needed to foment appropriate values. Restructuring power relations at the private and public levels is another must if unsustainable inequities 
(grounded not only in inter-gender differences, but also in intra-gender ones) are to be overcome. To that end, the involvement of society as a whole is essential, translating the right to participate into an effective tool for forging consensus on how the development model should be changed. In this respect, Tomás Carpi's definition of sustainable development represents an interesting starting point, which could be strengthened if it addressed the issue of care provision and the considerations of feminist economists.

Having explored the potential synergies, we have presented an integrative vision of sustainability that represents the fluid multidimensionality of life in the socioecological system. We have highlighted the fundamental interconnections between humanity and nature, between the private and public spheres, and between the market economy and households. This holistic approach requires new values, cooperative relations, and a non-dualistic understanding of life. Emotional and material needs are considered equally important for well-being and the model must respect the resilience capacity of nature and human beings.

Since the challenges faced by humanity at this particular moment of crisis call not only for ideas, but also for political action to bring about the required transformation, a committed leadership with a deep understanding of those challenges is essential. Achieving an integrative sustainability, supported by a society that is fully aware of its rights and responsibilities, is feasible, but it will require decisive, collective action.

\section{Bibliography}

Agarwal, Bina (1992), "The gender and environment debate: lessons from India", Feminist Studies, vol. 18, No. 1, College Park, Maryland, Feminist Studies Inc.

Agra Romero, María Xosé (comp.) (1998), Ecología y feminismo, Granada, Comares.

Almenar Asensio, Ricardo (2008), "Indicadores de sostenibilidad", Estrategias y elementos para un desarrollo sostenible, Emérito Bono and Juan A. Tomás Carpi (eds.), vol. III-III, Valencia, Nau Llibres.

Biehl, Janet (1991), Rethinking Ecofeminist Politics, Boston, South End Press.

Bono Martínez, Emérito (2008a), "Cambio climático y sustentabilidad económica y social. Implicaciones sobre el bienestar social", CIRIEC-España, Revista de Economía Pública Social y Cooperativa, No. 61, Valencia, Centre International de Recherches et d'Informations sur l'Economie Publique, Sociale et Cooperative (CIRIEC).

(2008b), "Retos de la política medioambiental: Un enfoque global", Desafíos actuales de la política económica: Un enfoque estructural y social, J. Jordán Galduf and A. Sánchez (coords.), Navarra, Aranzadi.

Bosch, Anna, Cristina Carrasco and Elena Grau (2003), "Verde que te quiero violeta: Encuentros y desencuentros entre feminismo y ecologismo", La historia cuenta. Del crecimiento económico al desarrollo humano sostenible, Enric Tello, Spain, El Viejo Topo.

Bosselmann, Klaus (2004), "In search of global law: the significance of the Earth Charter", Worldviews: Global Religions, Culture, and Ecology, vol. 8, No. 1, Brill.

Bressers, Hans and Walter Rosenbaum (eds.) (2003), Achieving Sustainable Development: The Challenge of Governance across Social Scales, New York, Praeger Publishers.

Carrasco, Cristina (2009), "Mujeres, sostenibilidad y deuda social", Revista de Educación, special issue.

Carrasco, Cristina and Maribel Mayordomo (2000), "Los modelos y estadísticas de empleo como construcción social: La encuesta de población activa y el sesgo de género", Política y Sociedad, vol. 34, Madrid, Complutense University of Madrid.

Carrasco, Cristina and Mónica Serrano (2011), "Lights and shadows of household satellite accounts: the case of Catalonia, Spain", Feminist Economic, vol. 17, No. 2, Taylor \& Francis.

Carson, Rachel (1962), Silent Spring, New York.
Costanza, Robert (2003), "Ecological economics is post-autistic", Post-autistic Economics Review, vol. 20, No. 3 [online] http:// www.paecon.net/PAEReview/issue20/Costanza20.htm. (1994), "Three general policies to achieve sustainability", Investing in Natural Capital: The Ecological Economics Approach to Sustainability, AnnMari Jansson and others (eds.), Washington, D.C., Island Press.

Daly, Herman (2005), "Economics in a full world", Scientific American, vol. 293, No. 3, Scientific American, Inc., September. (1996), Beyond Growth. The Economics of Sustainable Development, Massachusetts, Beacon Press.

D'Eaubonne, Francoise (1974), Le feminisme ou la mort, Paris, P. Horay. De Beauvoir, Simone (1968), El segundo sexo, Buenos Aires, Siglo Veinte.

Del Saz, Salvador (2008), "Valoración económica de los bienes ambientales", Técnicas e instrumentos de gestión ambiental, vol. IV, Emérito Bono and Juan Antonio Tomás Carpi, Valencia, Nau Llibres.

DESA (Department of Economic and Social Affairs) (2009), Policy Brief, No. 20, United Nations [online] http://www.un.org/ en/development/desa/policy/publications/policy_briefs/ policybrief20.pdf.

Durán, María Ángeles (2012), El trabajo no remunerado en la economía global, Madrid, BBVA Foundation.

(2011), "El trabajo del cuidado en el marco macroeconómico", El trabajo del cuidado en América Latina y España, Documento de Trabajo, No. 54, Madrid, Fundación Carolina-CeALCI. (2001), "El análisis de exhaustividad en la economía española", Tiempos, trabajos y género, Cristina Carrasco (ed.), Barcelona, Publicacions Universitat.

Durán, María Angeles and Vivian Milosavljevic (2012), "Unpaid work, time use surveys and care demand forecasting in Latin America", Documento de Trabajo, No. 7, Madrid, BBVA Foundation.

ECLAC (Economic Commission for Latin America and the Caribbean) (2012), Sustainable Development 20 Years on from the Earth Summit: Progress, Gaps and Strategic Guidelines for Latin America and the Caribbean (LC/L.3346/Rev.1), Santiago, Chile. (2004), Roads towards gender equity in Latin America and the Caribbean (LC/L.2114(CRM.9/3)), Santiago, Chile.

Freedman, Jane (2004), Feminismo ¿Unidad o conflicto?, Madrid, Narcea S.A. 
Gender Equality Observatory for Latin America and the Caribbean/ Economic Commission for Latin America and the Caribbean (ECLAC) (2010), "Indicadores de género", Santiago, Chile.

Grossman, Britt (1999), "Pollution tax", Encyclopedia of Law and Economics [online] http://murallivre.net/Archives/2500book.pdf.

Heller, Chaia (1999), Ecology of Everyday Life: Rethinking the Desire of Nature, Montreal, Black Rose Books.

Hochschild, Arlie (2004), "Las cadenas mundiales de afecto y asistencia", En el límite: La vida en el capitalismo global, Anthony Giddens and Will Hutton (eds.), Barcelona, Tusquets.

Howie, Gillian and Ashley Tauchert (2002), "Feminist dissonance: the logic of late feminism", Third Wave Feminism, Stacy Gillis, Gillian Howie and Rebecca Munford (eds.), Basingstoke, Palgrave.

Humphrey, Mathew (ed.) (2001), Political Theory and the Environment. A Reassessment, London, Frank Cass Publishers.

Jolly, Susie (2004), "Gender myths", BRIDGE [online] http://www. bridge.ids.ac.uk/go/home\&id=52913\&type=Document.

Kao, Grace (2010), "The universal versus the particular in ecofeminist ethics", Journal of Religious Ethics, vol. 38, No. 4, Wiley.

Klasen, Stephan and Dana Schüler (2011), "Reforming the genderrelated development index and the gender empowerment measure: implementing some specific proposals", Feminist Economics, vol. 17, No. 1, Taylor \& Francis.

Kriström, B. (1995), "Theory and applications of the contingent valuation method", paper prepared for the course "Economía ambiental: Valoración, recursos naturales y política económica", Barcelona, Universidad Internacional Menéndez y Pelayo, June.

Martínez Alier, Joan (2007), "El ecologismo popular", Ecosistemas, vol. 16, No. 3, Madrid, Asociación Española de Ecología Terrestre.

Meadows, Donella and others (1972), The Limits to Growth, New York, Universe Books.

Mellor, Mary (1997), Feminism and Ecology, Cambridge, Polity Press.

Merchant, Carolyn (1995), Earth Care: Women and the Environment, New York, Routledge.

Mies, María and Vandana Shiva (1997), Ecofeminismo. Teoría, crítica y perspectiva, Barcelona, Icaria.

Montaño Virreira, Sonia (2011), "Las políticas de cuidado en América Latina", El trabajo del cuidado en América Latina y España, Documento de Trabajo, No. 54, Madrid, Fundación Carolina -CeALCI.

(2010), "El cuidado en acción", El cuidado en acción. Entre el derecho y el trabajo, Cuadernos de la CEPAL series, No. 94 (LC/G.2454-P), Sonia Montaño Virreira and Coral Calderón Magaña (coords.), Santiago, Chile, Economic Commission for Latin America and the Caribbean (ECLAC). United Nations publication, Sales No. S.10.II.G.35.

Moore, Niamh (2004), "Ecofeminism as a third wave feminism? Essentialism, activism and the Academy", Third Wave Feminism, Stacy Gillis, Gillian Howie and Rebecca Munford (eds.), New York, Palgrave MacMillan.

Naredo, José Manuel (2006), Raíces económicas del deterioro ecológico y social. Más allá de los dogmas, Madrid, Siglo XXI.

Nash, Roderick Frizier (1989), The Rights of Nature: A History of Environmental Ethics, Wisconsin, The University of Wisconsin Press.

North, Douglas (1991), Institutions, Institutional Change and Economic Performance, Cambridge, Cambridge University Press.

Novo, María (coord.) (2007), Mujer y medio ambiente. Los caminos de la visibilidad: Utopías, educación y nuevo paradigma, Madrid, Los libros de la Catarata.

Picchio, Antonella (2005), "La economía política y la investigación sobre las condiciones de vida", Por una economía sobre la vida, Gemma Cairó i Céspedes and Maribel Mayordomo (comps.), Barcelona, Icaria-Más Madera.
(2001), "Un enfoque macroeconómico ampliado de las condiciones de vida", Tiempos, trabajos y género, Cristina Carrasco (ed.), Barcelona, Publicacions Universitat.

Pigou, Arthur Cecil (1932), The Economics of Welfare, London, MacMillan and Co. Originally published in 1920.

Pla Julián, Isabel (2009), "La feminización de las migraciones y la cadena global de cuidados" [online] http://www.agenciasinc. es/Opinion/La-feminizacion-de-las-migraciones-y-la-cadenaglobal-de-cuidados.

(coord.) (2008), "Luces y sombras del recurso al empleo de hogar", Quaderns Feministes, No. 8, Valencia, University of Valencia.

Plumwood, Val (2002), Environmental Culture: The Ecological Crisis of Reason, New York, Routledge.

(1993), Feminism and the Mastery of Nature, London, Routledge. (1991), "Nature, self, and gender: feminism, environmental philosophy, and the critique of rationalism", Hypatia, vol. 6, No. 1, Ecological Feminism.

Puleo, Alicia (2008), "Libertad, igualdad, sostenibilidad. Por un ecofeminismo ilustrado", Isegoría. Revista de Filosofía Moral y Política, No. 38, Madrid, Instituto de Filosofía, January-June. (2007), “QQue é o ecofeminismo?”, Andaina: Revista do Movemento Feminista Galego, No. 47, Asociación Galega da Muller Pan e Rosas.

(2002), "Feminismo y ecología: Un repaso a las diferentes corrientes de ecofeminismo", El Ecologista, No. 31, Madrid, Ecologistas en Acción.

Redclift, Michael (2009), "Sustainable development (1987-2005) - an oxymoron comes of age", Problems of Sustainable Development, vol. 4, No. 1 [online] http://ssrn.com/abstract=1481709.

Ress, Mary Judith (2003), "Reflexiones sobre el ecofeminismo en América Latina", Religión y género, Sylvia Marcos (ed.), Madrid, Trotta.

Rivera, María Milagros (1991), "La historia de las mujeres y la conciencia feminista en Europa", Mujeres y sociedad: Nuevos enfoques teóricos y metodológicos, Lola Luna (ed.), Barcelona, University of Barcelona.

Rocheleau, Dianne, Barbara Thomas-Slayter and Esther Wangari (eds.) (1996), Feminist Political Ecology: Global Issues and Local Experiences, New York, Routledge.

Rodríguez Enríquez, Corina (2012), "Care: the missing link in economic analysis", CEPAL Review, No. 106 (LC/G.2518-P), Santiago, Chile, April.

Salleh, Ariel (1997), Ecofeminism as Politics: Nature, Marx and the Postmodern, London, Zed Books.

(1992), "The ecofeminism/deep ecology debate: a reply to patriarchal reason", Environmental Ethics, vol. 14, No. 3, Charlottesville, Philosophy Documentation Center.

Sánchez, Cristina (2001), "Genealogía de la vindicación”, Feminismos. Debates teóricos contemporáneos, Elena Beltrán and others, Madrid, Alianza Editorial.

Schmid, Alfred Allan (1987), Property, Power and Public Choice. An Inquiry into Law and Economics, New York, Praeger.

Sessions, Robert (1991), "Deep ecology versus ecofeminism: healthy differences or incompatible philosophies?", Ecological Feminism, vol. 6 , No. 1, Hypatia.

Social Watch (2012), "El índice de equidad de género 2012" [online] http://www.socialwatch.org/es/node/14380. (2011), "What is sustainable development? The evolution of the idea" [online] http://www.socialwatch.org/sites/default/files/ report2011_sustainableDevelopment_0.pdf.

Stoddart, Mark C.J. and David B. Tindall (2011), "Ecofeminism, hegemonic masculinity and environmental movement participation in British Columbia, Canada, 1998-2007: 'Women always clean up the mess"', Sociological Spectrum, vol. 31, No. 3, Taylor \& Francis. 
Tomás Carpi, Juan Antonio (2008), "El desarrollo local sostenible en clave estratégica”, CIRIEC-España. Revista de Economía Pública Social y Cooperativa, No. 61, Valencia, Centre International de Recherches et d'Informations sur l'Economie Publique, Sociale et Cooperative (CIRIEC), August.

(2007), "Desarrollo sostenible", Estrategias y elementos para un desarrollo sostenible, vol. I-III, Emérito Bono and Juan Antonio Tomás Carpi (dirs.), Valencia, Nau Llibres.

UNDP (United Nations Development Programme) (2011), Human Development Report 2011. Sustainability and Equity: A Better Future for All [online] http://hdr.undp.org/en/reports/global/ hdr2011/.

UNEP (United Nations Environment Programme) (coord.) (2005), The Millenium Ecosystems Assessment [online] http://www. millenniumassessment.org.

UNESCO (United Nations Educational, Scientific and Cultural Organization) (2009), "Bonn Declaration" [online] http:// www.esd-world-conference-2009.org/fileadmin/download/ ESD2009_BonnDeclaration080409.pdf.

United Nations Conference on Sustainable Development (2012), "The future we want" [online] http://www.uncsd2012.org/ thefuturewewant.html.

United Nations General Assembly (2003), Resolution adopted by the General Assembly. United Nations Decade of Education for Sustainable Development (A/RES/57/254) [online]
http://www.un.org/ga/search/view_doc.asp?symbol=A/ RES/57/254\&referer=http://www.un.org/depts/dhl/resguide/ r57.htm\&Lang=S.

(1987), Report of the World Commission on Environment and Development (A/42/427) [online] http://www.un.org.

Valcárcel, Amelia (2008), Feminismo en el mundo global, Madrid, Cátedra.

(1993), Del miedo a la igualdad, Barcelona, Crítica.

Vig, Norman and Regina Axelrod (eds.) (1999), The Global Environment: Institutions, Law and Policy, London, Earthscan.

Walker, Brian and others (2004), "Resilience, adaptability and transformability in social-ecological systems", Ecology and Society, vol. 9, No. 2 [online] http://www.ecologyandsociety. org/vol9/iss2/art5.

Warren, Karen J. (2009), "Le pouvoir et la promesse de l'écofeminisme", Multitudes, vol. 1, No. 36.

Warren, Karen J. and Jim Cheney (1991), "Ecological feminism and ecosystem ecology", Ecological Feminism, vol. 6, No. 1, Hypatia Inc.

Young, Oran and others (2006), "The globalization of socio-ecological systems: an agenda for scientific research", Global Environmental Change, vol. 16, No. 3, Amsterdam, Elsevier.

Zimmerman, Michael E. (1987), "Feminism, deep ecology and environmental ethics", Environmental Ethics, vol. 9, No. 1, Charlottesville, Philosophy Documentation Center. 